Volume $10 \quad$ Nomor 3, Desember 2020

Halaman $285-294$

\title{
TINDAK TUTUR BAHASA JEPANG PADA MEDIA SOSIAL INSTAGRAM DI MASA PANDEMI COVID-19: SUATU KAJIAN PRAGMATIK
}

\author{
Irzam Sarif S. \\ Fakultas Ilmu Budaya Unpad \\ rzamsarifs@yahoo.com \\ Nani Darmayanti \\ Fakultas Ilmu Budaya Unpad \\ n.darmayanti@unpad.ac.id
}

\begin{abstract}
Abstrak
Tindak tutur adalah aktivitas mengujarkan tuturan dengan maksud tertentu. Penelitian mengenai tindak tutur telah banyak dilakukan oleh peneliti sebelumnya, namun jumlahnya masih terbatas yang mengkaji mengenai tindak tutur di masa pandemi Covid19. Penelitian ini membahas mengenai jenis-jenis tindak tutur di media sosial Instagram pada masa Covid-19. Penelitian ini menggunakan pendekatan pragmatik dengan teori tindak tutur Searle (1979). Metode yang digunakan berupa deskriptif kualitatif. Berdasarkan dari hasil analisis data, peneliti menemukan 3 jenis tindak tutur, yaitu 1) Tindak tutur direktif dengan implikatur membujuk dan menyemangati; 2) Tindak tutur representatif dengan implikatur memerintah dan memberi tantangan; 3) Tindak tutur ekspresif dengan implikatur menyemangati.
\end{abstract}

Kata Kunci: Covid-19, Pragmatik, Tindak tutur

\begin{abstract}
Speech act is the activity of uttering speech with a specific purpose. Research on speech acts has been done by many researchers before, but the number is still limited that reviewed the speech acts during the Covid-19 pandemic. This study discussed the types of speech acts on Instagram social media during the Covid-19 period. This study used a pragmatic approach with Searle's speech act theory (1979). The method used is descriptive qualitative. Based on the results of data analysis, researcher found that 3 types of speech acts, namely 1) Directive speech acts with the implicature of persuading and encouraging; 2) Representative speech acts with the implicature of commanding and challenging; 3) Expressive speech acts with the implicature of encouraging.
\end{abstract}

Keywords: Covid-19, Pragmatic, Speech act

\section{PENDAHULUAN}

Bahasa merupakan media penghubung, media komunikasi di antara individu satu dengan individu lain sebagai individu dalam berpikir, merasa, dan berkeinginan. Semua hal tersebut baru akan berwujud bila diungkapkan dan dinyatakan dalam bentuk bahasa.

Proses berbahasa dapat dilakukan dengan dua tahap, yaitu (1) proses penyampaian pikiran atau perasaan seseorang kepada orang lain dengan 
menggunakan lambang (symbol) (Uchjana, 2006: 11). Lambang itu berupa bahasa, gambar, warna, dan lain sebagainya yang secara langsung mampu mewakili pikiran dan atau perasaan komunikator kepada komunikan; (2) proses penyampaian pesan oleh seseorang kepada orang lain dengan menggunakan alat atau sarana sebagai media kedua setelah memakai lambang sebagai media pertama (Uchjana, 2006: 16).

Kedua tahap ini sebenarnya bisa dirasakan bersama secara bersamaan melalui adanya media sosial. Salah satu media sosial yang paling hits dewasa ini adalah Instagram. Instagram merupakan media sosial yang mana semua individu dapat berkomunikasi secara bebas, mengekspresikan diri melalui katakata dan gambar secara bersamaan. Tak jarang jika orang-orang saat ini memakai media sosial. Banyaknya pengguna media sosial seperti Instagram memudahkan orang untuk berkomunikasi. Maka, proses penyampaian pikiran atau perasaan oleh seseorang kepada orang lain dapat dilakukan dengan baik, melalui lambang-lambang yang bermakna bagi kedua pihak, dalam situasi yang tertentu, menggunakan media tertentu dalam mengubah sikap atau pandangan orang-orang yang akan menimbulkan efek tertentu sesuai yang diharapkan (Effendy, 2003:13).

Penggunaan media sosial bertambah riuh ketika wabah penyakit melanda belakangan ini. Banyak kegiatan ataupun pekerjaan tertunda disebabkan virus baru yang muncul, yaitu Covid-19. Mau tak mau orang-orang lebih cenderung beraktivitas dari rumah, semua kegiatan serba online. Penggunaan media sosial pun tak kalah meningkat. Aktivitas banyak terwakili secara online dalam media sosial, seperti Instagram. Di Instagram, orang-orang bebas dalam berekspresi, berkomunikasi dan bertutur karena instagram memiliki fitur-fitur yang mewakili ujaran-ujaran kita dalam bertindak tutur di media sosial. Hal ini sejalan dengan penjelasan Yule (2006: 82) bahwa tindak tutur yaitu tindakan-tindakan yang ditampilkan lewat tuturan. Karena dalam ujaran selalu memiliki maksud tertentu yang melatar belakangi ujaran, maksud itulah yang dapat menimbulkan pengaruh tertentu terhadap orang lain, seperti halnya mencubit atau memukul. Dengan demikian tindak tutur adalah aktivitas mengujarkan tuturan dengan maksud tertentu.

Berdasarkan pada pemaparan di atas, hal tersebut dapat dikaji dalam ilmu bahasa dengan menggunakan kajian pragmatik. Pada kajian pragmatik terdapat teori tindak tutur. Tindak tutur merupakan pandangan yang menegaskan bahwa sebuah ungkapan suatu bahasa yang dapat dipahami dan dimengerti dengan baik, apabila dikaitkan dengan situasi konteks terjadinya ungkapan tersebut yang kemudian memunculkan sebuah makna. Searle (1969: 16) berpendapat bahwa "The unit of linguistic communication is not, as has generally been supposed, the symbol, word or sentence, or even the token of the symbol, word or sentence, but rather the production or issuance of the symbol or word or sentence in the performance of the speech act". Ia menjelaskan bahwa komunikasi tidak hanya sekedar lambang, kata atau kalimat, tetapi akan lebih tepat apabila komunikasi disebut produk atau hasil dari lambang, kata atau kalimat yang berwujud perilaku tindak tutur (the performance of the speech act). 
Austin (1962) dalam bukunya yang berjudul "How to Do Thing with Words" menyebutkan bahwa tindak tutur di bagi menjadi tiga macam, 1) Tindak Lokusi adalah tindakan mengucapkan sesuatu dengan kata dan makna kalimat yang ditetapkan; 2) Tindak Ilokusi adalah tindakan yang mempunyai makna terkandung dalam tuturan, yaitu berusaha untuk mempengaruhi lawan tutur dengan melakukan sesuatu atas tuturannya; 3) Tindak Perlokusi adalah tindakan untuk mempengaruhi pendengarnya atau tindak tutur yang memiliki daya pengaruh atau efek bagi lawan tuturnya.

Lanjut, jika Austin menelaah tindakan tutur itu dari segi penutur sedangkan Searle (1979) menelaah tindak tutur itu dari segi petutur, sehingga ia mengklasifikasikan tindak tutur berdasarkan maksud penutur (hal yang akan dipikirkan oleh petutur) menjadi lima kelompok besar, yakni 1) Tindak tutur representatif yaitu tindak tutur berfungsi untuk memberi tahu orang-orang mengenai sesuatu. Tindak tutur ini mencakup; mempertahankan, meminta, mengatakan, menyatakan dan melaporkan; 2) Tindak tutur komisif yaitu tindak tutur yang menyatakan bahwa penutur akan melakukan sesuatu, misalnya janji dan ancaman; 3) Tindak tutur direktif yaitu tindak tutur yang berfungsi untuk membuat petutur melakukan sesuatu seperti saran, permintaan dan perintah; 4) Tindak tutur ekspresif yaitu tindak tutur yang berfungsi untuk mengekspresikan perasaan dan sikap mengenai keadaan hubungan, misalnya permintaan maaf, penyesalan dan ungkapan terima kasih; 5) Tindak tutur deklaratif yaitu tindak tutur yang menggambarkan perubahan dalam suatu keadaan hubungan, misalnya ketika kita memundurkan diri dengan mengatakan: "Saya mengundurkan diri, memecat seseorang dengan mengatakan; "adinda dipecat", atau menikahi seseorang dengan mengatakan "saya bersedia".

Konteks dalam pragmatik sangat penting dalam mengartikan sebuah kalimat yang diucapkan oleh penutur karena bahasa selalu diungkapkan dalam sebuah konteks. Konteks dalam bahasa Jepang disebut bunmyaku (文脈). Pentingnya konteks juga dijelaskan oleh Koizumi (2001:35) bahwa "Dari pengalaman sehari-hari yang kita ketahui, konteks merupakan suatu bagian yang berperan penting dalam komunikasi yang kita lakukan, baik dalam "makna eksplisit" maupun "makna implisit.

Beberapa penelitian relevan mengenai penelitian ini yaitu yang pertama oleh Martawijaya (2019) dengan judul "Analisis Tindak Tutur Menyatakan Pendapat dalam Drama Seri "1 Rittoru no Namida". Penelitian ini bertujuan untuk mengkaji tindak tutur yang menyatakan pendapat dalam percakapan sehari-hari dengan melihat konstruksi yang digunakan dan maknanya. Penelitian ini dibatasi pada tindak tutur menyatakan pendapat atau fakta pada percakapan dalam drama seri " 1 Rittoru no Namida". Metode yang digunakan adalah metode deskriptif. Penelitian kedua oleh Faramida (2019) dengan judul "Tindak Tutur Representatif pada Caption Instagram". Penelitian ini bertujuan untuk mengidentifikasi semua caption yang memiliki tindak tutur representatif, mengklasifikasikan tindak tutur representatif berdasarkan bentuk, menganalisis setiap jenis tindak tutur representatif. Metode yang dipakai dalam penelitian ini 
adalah penelitian kualitatif. Teknik pengumpulan data dalam penelitian ini adalah teknik rekam dan teknik catat.

Berpijak dari uraian di atas, tuturan-tuturan yang muncul berupa istilahistilah baru dapat dilihat sebagai sebuah fenomena bahasa sebab hal tersebut sesuai dengan beberapa fungsi bahasa yaitu sebagai alat komunikasi, alat untuk mengapresiasikan diri, sebagai alat untuk berkomunikasi dan sebagai alat untuk melakukan kontrol sosial (Keraf, 1997;1). Dalam hal ini, peneliti tertarik untuk mengkaji lebih lanjut mengenai jenis-jenis tuturan yang muncul selama masa pandemi Covid-19 dan melihat implikatur atau maksud dari tuturan tersebut pada media sosial instagram dengan pendekatan teori pragmatik khususnya tindak tutur Searle (1979).

\section{METODE PENELITIAN}

Penelitian ini adalah jenis penelitian kualitatif yang menggunakan metode deskriptif karena penelitian ini hanya terfokus pada jenis-jenis tindak tutur yang terdapat pada Instagram di masa pandemi Covid-19. Penelitian kualitatif merupakan penelitian yang bermaksud untuk memahami fenomena tentang apa yang dialami oleh subjek penelitian misalnya perilaku, presepsi, motivasi, tindakan dan dengan cara deskripsi dalam bentuk kata-kata dan bahasa, pada suatu konsep khusus yang alamiah dan dengan memanfaatkan berbagai metode ilmiah (Moleong, 2000: 6).

Sumber data dalam penelitian ini di ambil dari media sosial Instagram berbahasa Jepang. Adapun data diambil berupa ujaran-ujaran di sosial media selama masa pandemi di Jepang. Teknik pengumpulan data menggunakan metode simak, dengan teknik dasar dari metode ini yaitu teknik catat dengan maksud untuk mencatat data yang sudah disimak dari sumber data.

Analisis data merupakan upaya peneliti menangani langsung masalah yang terkandung dalam data (Sudaryanto, 1993:6). Analisis data dalam penelitian ini menggunakan metode padan. Teknik dasar dalam penelitian ini adalah teknik pilah unsur penentu atau teknik PUP. Adapun alatnya adalah daya pilah yang bersifat mental yang dimiliki oleh peneliti. Daya pilah yang dimaksud adalah daya pilah referensial. Melalui daya pilah tersebut dapat diketahui jenis tindak tutur yang diucapkan penutur melalui konteksnya. Untuk itu, dalam mendapatkan korpus data penulis melakukan beberapa hal, di antaranya penulis melakukan transliterasi pada data yang telah ditemukan. Setelah itu, data tersebut diterjemahkan ke dalam bahasa Indonesia untuk membantu penulis dalam memahami dan menganalisis teks data tersebut. Setelah diterjemahkan, kemudian dilakukan pengolahan data dengan mengamati dan menganalisis ujaran-ujaran yang terkait dengan tindak tutur. Kemudian, peneliti mencatat dan mengklasifikasi tuturan-tuturan tersebut berdasarkan ke dalam penjenisan tindak tutur. Setelah itu, data yang berupa tuturan tersebut dianalisis dengan menggunakan pendekatan pragmatik yakni pendekatan yang selalu berkaitan dengan konteks yang mewadahi dan melatarbelakangi sebuah tuturan dan implikaturnya. 


\section{HASIL DAN PEMBAHASAN}

Penelitian ini diklasifikasi dan dianalisis berdasarkan jenis tindak tutur yang ditemukan pada masa pandemi virus Korona di Jepang. Adapun pemaparannya diuraikan sebagai berikut.

\section{Tindak Tutur Direktif}

$\begin{array}{ll}\text { Eksplikatur } & \text { : お家で過ごそう } \\ & \text { /oie de sugosou/ } \\ & \text { 'Mari habiskan waktu di rumah' } \\ \text { Penanda } & : \text { 過ごそう } \\ \text { Konteks } & \text { Tuturan wacana di atas diperoleh dari berbagai hashtag dengan } \\ & \text { postingan gambar kegiatan selama di rumah. } \\ \text { Tujuan } & \text { : Tuturan ajakan berimplikatur membujuk untuk melakukan } \\ & \text { segala aktivitas di rumah agar terhindar dari penyakit Covid- } \\ & 19 .\end{array}$

Data di atas merupakan tindak tutur direktif mengajak. Melalui tuturan tersebut penanda sugosou 過ごそう ‘Ayo menghabiskan’ penutur mengajak untuk melakukan sesuatu sebagaimana yang diinginkan oleh penutur, yakni bersama-sama untuk melakukan segala aktivitas di rumah agar terhindar dari penyakit covid-19. Konteks wacana di atas adalah berbagai aktivitas selama di rumah yang diposting oleh beberapa akun. Adanya unsur mengajak dalam konteks ini adalah hal yang bertujuan untuk meminta supaya mitra tutur menuruti sebagaimana yang diinginkan oleh penutur untuk melakukan suatu tindakan. Dengan demikian, tindakan yang dilakukan oleh mitra tutur adalah untuk mengajak orang-orang sekitar menghabiskan waktu di rumah.

(https://www.instagram.com/p/B-L2tNGpTrl/)

$\begin{array}{ll}\text { Eksplikatur } & \text { : お家にいよう } \\ & \text { /oie ni iyou/ } \\ & \text { 'Mari tetap di rumah' } \\ \text { Penanda } & \text { : いよう } \\ \text { Konteks } & \text { : Tuturan wacana di atas diperoleh dari hashtag dengan } \\ & \text { postingan gambar kegiatan di rumah. } \\ \text { Tujuan } & \text { : Tuturan ajakan berimplikatur membujuk untuk melakukan } \\ & \text { segala aktivitas di rumah agar terhindar dari penyakit covid- } \\ & \text { 19. }\end{array}$

Data di atas merupakan tindak tutur direktif mengajak. Melalui tuturan tersebut penanda iyou いよう ‘Ayo tinggal' dengan objek ‘oie’ お家 ‘ rumah' penutur mengajak untuk melakukan sesuatu sebagaimana yang diinginkan olehnya, yaitu agar tetap berada di rumah untuk menghindari penyakit Covid-19. Data ini mempunyai maksud yang sama dengan tujuan data sebelumnya, namun dengan bentuk tuturan yang berbeda. Oleh karena itu, 
ajakan pada data ini bertujuan untuk meminta semua orang agar tetap di rumah untuk mencegah penyebaran virus korona.

(https:/ / www.instagram.com/p/CBnk7nvp7rY/)

Selain tuturan-tuturan mengajak di atas terdapat juga tuturan mengajak dalam ungkapan yang berbeda seperti / fuyō fukyū no gaishutsu jishuku/ 不要 不急の外出自肅 ‘Tidak perlu keluar’，/sutei hoomu/ ステイホーム ‘Tetap di rumah'.

$\begin{array}{ll}\text { Eksplikatur } & \text { : コロナに負けるな } \\ & \text { / koronani makeruna/ } \\ & \text { 'Jangan kalah dari korona' } \\ \text { Penanda } & \text { : 負けるな } \\ \text { Konteks } & \text { Tuturan wacana di atas diperoleh dari akun-akun yang } \\ & \text { memposting sejumlah gambar tulisan dan relawan medis. } \\ \text { Tujuan } & \text { : Tuturan memerintah berimplikatur menyemangati tim medis } \\ & \text { dalam bentuk kalimat imperatif untuk menghadapi virus } \\ & \text { korona. }\end{array}$

Data di atas merupakan tindak tutur direktif perintah yaitu suatu tindak tutur yang melarang agar mitra tutur melakukan sesuatu sebagaimana yang diminta oleh penutur, dengan tuturan 'Jangan kalah’ makeruna 負けるな. Tuturan ini berasal dari kata makeru 負ける yang artinya kalah kemudian mengalami konjugasi imperative 〜な sehingga menjadi makeruna 負けるな yang artinya jangan kalah. Tuturan yang dikatakan oleh penutur ini merupakan tuturan untuk menyemangati tim medis dalam menghadapi virus korona karena telah banyak yang tumbang bahkan merenggut nyawa tim medis. (https://www.instagram.com/p/CAjN8ofnadj/)

\section{Tindak Tutur Representatif}

Eksplikatur : コロナ太り

/koronafutori/

'Korona Gemuk'

Penanda : 太り

Konteks : : Tuturan wacana tersebut diperoleh dari akun-akun wanita dengan gambar badan dan juga makanan di masa pandemi Covid-19.

Tujuan : Tuturan pernyataan berimplikatur peringatan di tengah wabah virus korona.

Data di atas merupakan tindak tutur representatif pernyataan yaitu berfungsi untuk memberi tahu orang-orang mengenai sesuatu. Pada tuturan koronafutori コロナ太り 'Korona Gemuk', jika ditinjau dari segi pembentukan katanya, istilah tersebut merupakan kata majemuk yang terdiri dari kata korona コロナ ‘korona’ dan futori 太り 'gemuk' . Jika diartikan, maka akan bermakna 'orang-orang menjadi gemuk karena korona' . Konteks 290 | METAHUMANIORA, Volume 10 Nomor 3, Desember 2020, 285 - 294 
dari lahirnya istilah ini adalah kebanyakan dari akun wanita memposting gambar badan dan juga makanan selama masa pandemi ini. Tak sedikit dari mereka yang mengeluh mengenai bentuk badan mereka sendiri. Namun ada juga beberapa yang mengaku bahagia.

(https://www.instagram.com/p/CBmkN7YjFTD/)

Tuturan yang dikatakan oleh penutur merupakan masalah berat badan di masa pandemi virus korona ini. Kurang olahraga karena menahan diri untuk tidak keluar dianggap sebagai penyebab utama kelebihan berat badan korona. Ada juga yang mengatakan bahwa salah satu faktor yang berkontribusi terhadap kelebihan berat badan korona adalah stres.

Bukti dari beberapa twit akun yang diambil, seorang pria pekerja kantoran berusia 55 tahun berkata, 'Saya pikir saya memperoleh sekitar 3 kilometer. Saya dulu berjalan 10.000 langkah sehari, tapi sekarang saya hanya berjalan sekitar 2000 langkah dan keluar. Saya hanya bermain golf seminggu sekali.'

(https://www.instagram.com/p/CBpTQlcDZ_d/)

Seorang wanita yang bekerja paruh waktu juga mengatakan 'Saya keluar dan menjadi tidak aktif, dan sambil makan lebih banyak, saya mendapatkan sekitar $2 \mathrm{~kg}^{\prime}$. Ada juga seorang wanita berusia 18 tahun yang memasuki sekolah kejuruan berkata, 'Saya telah menjadi sedikit tidak teratur dalam hidup saya dan telah bertambah sedikit berat badan. Saya ingin berjalan sebanyak mungkin.' (https://www.instagram.com/p/CBpO_YJhsau/)

Oleh karena itu, tuturan itu adalah tuturan yang termasuk ke wujud tuturan representatif untuk menyatakan sesuatu di tengah wabah virus korona ini.

Eksplikatur : コロナ離婚

/koronarikon/

'Perceraian Korona

Penanda : 離婚

Konteks : : Tuturan wacana tersebut diperoleh dari akun-akun yang memposting tulisan-tulisan galau utamanya dari akun wanita.

Tujuan : Tuturan pernyataan berimplikatur peringatan di tengah wabah virus korona.

Data di atas merupakan tindak tutur representatif pernyataan yaitu berfungsi untuk memberi tahu orang-orang mengenai sesuatu. Pada tuturan koronarikon コロナ離婚 ‘Perceraian korona', jika ditinjau dari segi pembentukan katanya, istilah tersebut merupakan kata majemuk yang terdiri dari kata korona コロナ ‘korona' dan rikon 離婚 ‘cerai’ . Jika diartikan, maka akan bermakna 'banyak orang bercerai akibat virus korona' . Konteks dari lahirnya istilah-istilah ini adalah kebanyakan dari akun istri yang mengeluh melihat kondisi keluarganya selama masa pandemi ini. Budaya orang Jepang ialah budaya pekerja, jadi jarang di antara mereka menghabiskan waktu bersama di rumah. Namun, selama pandemi, rata-rata pasangan suami istri lebih banyak 
menghabiskan waktu bersama di rumah ketimbang bekerja, sehingga banyak dari mereka memperlihatkan sifat buruknya dan tidak menyukai sifat pasangannya, lalu memutuskan untuk berpisah. (https://www.instagram.com/p/B_jOcX9JByQ/)

Oleh karena itu, tuturan itu adalah tuturan yang termasuk ke wujud tuturan representatif untuk menyatakan sesuatu di tengah wabah virus korona ini.

$\begin{aligned} \text { Eksplikatur } & \text { : アマビェチャレンジ } \\ & \text { /amabea charenji/ } \\ & \text { 'Tantangan Amabea' }\end{aligned}$

Penanda : チャレンジ

Konteks : : Tuturan wacana tersebut diperoleh dari banyak akun yang memposting gambar-gambar putri duyung yang memiliki paruh.

Tujuan : Tuturan pernyataan berimplikatur memberi tantangan kepada orang-orang untuk mengusir virus korona.

Data di atas merupakan ekspresif yaitu suatu tindak tutur yang melarang agar mitra tutur melakukan sesuatu sebagaimana yang diminta oleh penutur, tuturan charenji チャレンジ ‘Tantangan’ yang dikatakan oleh penutur merupakan "Amabea" sedang booming di seluruh Jepang. Ini adalah youkai dengan legenda yang muncul di laut Kumamoto pada periode Edo, bentuknya seperti putri duyung, namun memiliki paruh. Menurut legenda bahwa wabah akan berhenti jika "amabea" ini dilukis dan disebarkan. Kemudian hal ini menjadi populer sejak korona virus baru mulai berkembang dengan maksud agar virus ini segera hilang. (https://www.instagram.com/p/Be0v8vAA8j/)

\section{Tindak Tutur Ekspresif}

$\begin{array}{ll}\text { Eksplikatur } & \text { : ありがとうコロナファイターズ } \\ & \text { /arigatou korona faitaazu/ } \\ & \text { 'Terima kasih para pejuang korona' } \\ \text { Penanda } & \text { : ありがとう } \\ \text { Konteks } & \text { : Tuturan wacana tersebut diperoleh dari akun-akun yang } \\ & \text { memposting gambar-gambar tulisan, tim medis dan juga } \\ & \text { bingkisan hadiah. } \\ \text { Tujuan } & \text { : Tuturan terima kasih berimplikatur menyemangati tim medis } \\ & \text { di tengah menghadapi virus korona. }\end{array}$

Data di atas merupakan tindak tutur ekspresif berterima kasih yaitu suatu tindak tutur yang menyatakan rasa terima kasih melalui tuturannya, Pada tuturan arigatou ありがとう ‘terima kasih’ yang dikatakan oleh penutur merupakan tuturan momentum untuk mendukung staf medis dan keluarga mereka untuk mencegah runtuhnya perawatan medis di Jepang. Bentuk terima 
kasih itu juga berupa pengiriman bir ke semua staf medis dan pejuang korona yang ikut serta memerangi virus Korona.

Bentuk tuturan ini juga muncul sebab para tim dan relawan medis didiskriminasi dan diprasangkai hal-hal yang buruk, seperti penolakan untuk menerima pusat penitipan anak-anak dan penolakan pengiriman pasokan medis.

Oleh karena itu, muncul tuturan-tuturan rasa hormat dan penghargaan kepada semua profesional medis yang berjuang di garis depan bidang medis, seperti T-shirt 'terima kasih pekerja medis' dengan seragam jas putih. Ada juga dalam bentuk stiker maupun donasi yang di pos di berbagai akun media Instagram.

(https://www.instagram.com/p/CAeV5rDpw1N/?hl=ja)

Selain tuturan ekspresif di atas terdapat juga tuturan terima kasih dalam memberi semangat dalam ungkapan yang berbeda seperti ganbare korona faitaazu 頑張れコロナファイターズ ‘Semangat para pejuang korona’

\section{PENUTUP}

Pembahasan jenis tindak tutur pada media sosial Instagram di masa pandemi Covid-19 sangat menarik untuk diketahui makna dan konteks yang disampaikan dalam setiap ujarannya. Berdasarkan data yang dibahas sebelumnya, peneliti menemukan 3 jenis tindak tutur, yaitu 1) Tindak tutur direktif; 2) Tindak tutur representatif; 3) Tindak tutur ekspresif. Maksud dalam tuturan-tuturan dari data yang ditemukan merupakan sebuah fenomena bahasa sebagai upaya dalam berkomunikasi oleh penutur kepada mitra tutur, dengan tujuan direktif untuk membujuk sekaligus menyemangati agar orang-orang menghindari dan memutuskan penyebaran Covid-19. Tujuan lainnya dalam tindak tutur representatif yaitu untuk memberitahukan sekaligus memerintah dan memberi tantangan orang-orang dengan melihat kondisi-kondisi yang terjadi di tengah pandemi Covid-19 ini. Adapun tujuan dari tindak tutur ekspresif adalah untuk menyampaikan rasa terima kasih sekaligus menyemangati kepada para relawan dan tim medis yang selalu menjadi garda terdepan dalam mengatasi Covid-19.

\section{DAFTAR PUSTAKA}

Austin, J. L. (1962). How do to Things with Words. Oxford: The Clarendon Press. Effendy, O. U. (2003). Ilmu, Teori, dan Filsafat Komunikasi. Bandung: Citra Aditya Bakti.

Faramida, I., Charlina, \& Hermandra. (2019). Tindak Tutur Representatif pada Caption Instagram. JURNAL TUAH, 1(1), 8-17.

Keraf, Gorys. (1997). Komposisi: Sebuah Pengantar Kemahiran Bahasa. Ende-Flores: Nusa Indah. 
Koizumi, Tamotsu. (2001). Nyumon Goyouron Kenkyuu "Riron to Ouyou". Japan: Kabushiki Kaisha kenkyuusha.

Moleong, L. J. (2000). Metodologi Penelitian Kualitatif. Bandung: Remaja Rosda Karya

Permata Martawijaya, A. (2019). Analisis Tindak Tutur Menyatakan Pendapat Dalam Drama Seri "1 Rittoru No Namida." Journal of Japanese Language Education and Linguistics, 3(1), 56-80. https://doi.org/10.18196/jjlel.3124

Rahardi, Kunjana. (2003). Berkenalan dengan Ilmu Bahasa Pragmatik. Malang: Dioma.

Searle, J.R. (1969). Speech Act: An Essay in the Philosophy Of Language. Cambridge: Cambridge University Press.

Searle, J.R. (1979). Expression and Meaning Studies in the Theory of Speech Act. Cambridge: Cambridge University Press

Sudaryanto. (1993). Metode dan Teknik Analisis Bahasa. Yogyakarta: Duta Wacana University Press

Uchjana, Onong. (2006). Ilmu Komunikasi Teori dan Praktek. Bandung: PT Remaja Rosdakarya

Yule, George. (2006). Pragmatik. Yogyakarta: Pustaka Pelajar. 